\title{
Ege Bölgesi odun dışı orman ürünleri sanayinin mevcut durumu
}

\author{
Current status of non-wood forest products industry in Aegean Region
}

\author{
Hadiye BAŞAR ${ }^{1}$ \\ Fevzi BİLGİN ${ }^{2}$ \\ Mustafa Burak ARSLAN ${ }^{1}$
} ${ }^{1}$ Ege Ormancılık Araştırma Enstitüsü
Müdürlüğü, İzmir
${ }^{2}$ Batı Karadeniz Ormancılık Araştırma
Enstitüsü Müdürlüğü, Bolu

Sorumlu yazar (Corresponding author) Hadiye BAŞAR

hadiyebasar@ogm.gov.tr

Geliş tarihi (Received)

26.06.2020

Kabul Tarihi (Accepted)

21.10.2020

Sorumlu editör (Corresponding editor) Taner OKAN

tokan@istanbul.edu.tr

Atıf (To cite this article): Başar, H . (2021). Ege Bölgesi odun dışı orman ürünleri sanayinin mevcut durumu . Ormancılık Araştırma Dergisi , 8 (1) , 69-79. DOI: 10.17568/ogmoad.758590

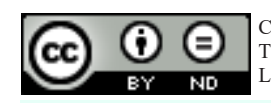

Creative Commons Atıf Atif Türetilemez 4.0 Uluslararas
Lisansı ile lisanslanmıștır.

\section{Öz}

Türkiye odun dişı orman ürünleri (ODOÜ) bakımından zengin olmasına ve ürünleri işleyen sanayilerin önemi gün geçtikçe artmasına rağmen sanayi koluna yönelik geniş değerlendirmeler içeren ve alansal verilere dayalı bilimsel çalışma ve incelemeler oldukça sınırlıdır. Bu durum ürün grubunu işleyen sanayilerin incelenmesini ve araştırmaların artırılmasını gerektirmektedir. Bu çalışmada, alan çalışmasına dayanılarak ODOÜ sanayisinin genel durumunun ortaya konulması, işletme yapılarının ve işletmeci özelliklerinin incelenmesi, sorunlarının ve beklentilerinin belirlenmesi, ODOÜ sanayisinin gelişimine yönelik bazı sonuçlara ulaşılması ve önerilerde bulunulması amaçlanmıştır. Çalışmanın kapsamını Ege Bölgesi örneğinde belirlenen illerdeki (İzmir, Manisa, Aydın, Denizli ve Muğla) ODOÜ sanayi işletmeleri oluşturmaktadır. Bölgede 105 firma ile yüz yüze görüşme yapılmıştır. İşletmelerin genel profilinin değerlendirilmesi ile \%89,5'ini mikro ve küçük ölçekli işletmelerin oluşturduğu görülmüş ve incelenen işletmelerin genel olarak kurumsallaşma sürecinin başında oldukları belirlenmiştir. Ürün dağılımı itibarıyla en çok işlenen ürünler sırasıyla kekik (61), defne (55), adaçayı (46) ve biberiye (41) olarak belirlenmiştir. İşletmelerin \%53,3'ünü limited şirketler oluşturmaktadır.

Anahtar Kelimeler: ormancılık, ODOÜ, sanayi, Ege Bölgesi

\begin{abstract}
Scientific studies and investigations, involving large assessments for these industries and based on the spatial data, are very limited in Turkey despite the richness of Turkey in non-wood forest products (NWFP) and the increasing importance of industrial processes day by day. This situation needs to increase the researches about industry processing fort his group of products. For this purpose, it was considered this project that provides conclusion and recommendations for, determine general situation of the NWFP industry with its problems and expectations, identify the current situation and development, examine the structure of the company and the keepers, investigate the development in forest-industry relations from demand and supply, in the light of information to be obtain with field work. The scope of the study is NWFP industries. Application areas are defined as İzmir, Manisa, Aydın, Denizli and Muğla. Face-to-face interviews were conducted with 105 companies in the region. With the evaluation of the general profile of the enterprises, it was seen that $89.5 \%$ of them were micro and small scale enterprises. It was determined that the enterprises examined with the study are generally at the beginning of the institutionalization process. In terms of product distribution, the most processed products were thyme (61), bay (55), sage (46) and rosemary (41), respectively. $53.3 \%$ of the enterprises are limited companies.
\end{abstract}

Keywords: forestry, NWFP, industry, Aegean Region 


\section{Giriş}

Odun diş1 orman ürünlerine (ODOÜ) olan talep, değişen tüketici tercihleri, hızlı kentleşme nedeniyle doğal kaynaklara erişim zorlukları, besin kirlenmesi, kullanım alanlarının çeşitlenmesi, farklı sanayi kollarının üretimde bu ürün grubunu yaygın olarak tercih etmesi vb. nedenlerle hızla artmaktadır. Yakın bir geçmişe kadar yalnızca yöresel kullanım ve pazarlarda gıda takviyesi şeklinde yer alan ODOÜ tüketimi şekil değiştirerek kendi sanayi kolu dışında kozmetik, boya, gıda, tekstil, enerji, ilaç vb. birçok sektörde önemli hammadde temin kaynağ 1 haline gelmiştir. Yapılan son çalışmalar bu ürün grubunun kırsal yörelere başta gıda ve geçim kaynağı olmak üzere tahmin edilenden daha fazla katkı sağladığını göstermektedir (Ickowitz ve ark., 2014).

Dünya genelinde olduğu gibi, Türkiye'de de bu gelişim kendini göstermektedir. Zengin bitki coğrafyası ve kırsal nüfus yoğunluğu ile gerek kırsal yörelere sağladığı katkı, gerekse iç ve dış ticarette gittikçe artan oranda ağırlığı ODOÜ'ni önemli bir ürün grubu haline getirmiştir. ODOÜ'nin çok önemli bir bölümü doğadan toplandığg ve orman arazilerinde yer aldığından orman kaynaklarının sürdürülebilir yönetimi ve orman köylerine katk1larının artırılması, orman-halk ilişkilerinin geliştirilmesi açısından bu kaynakların tek yöneticisi durumunda olan Orman Genel Müdürlüğüne (OGM) önemli görevler yüklemektedir. Bu duruma Türkiye Ulusal Ormancılık Programında da (2004-2023) yer verilmekte; ormanların korunması, geliştirilmesi, faydalanma ve orman köylerine yönelik amaç, hedef ve stratejileri arasında konunun önemi vurgulanmaktadir (Anonim, 2004).

ODOÜ sektörü, karşılaştırmalı üstünlükleri olan, ekonomik değeri yüksek ve arz açığı olan bir sektör olarak tanımlanmaktadır (Türker ve ark. 2006; Anonim, 2011). Diğer taraftan, Türkiye gibi ODOÜ zengini olan ülkelerin hammadde temini sağlayan ülkeler kategorisinde olması, buna karş1l1k bu ürünleri ithal eden Almanya, İspanya, İtalya, Çin gibi sanayisini kuran ve geliştiren ülkelerin hammadde olarak ithal ettikleri ürünleri işleyerek mamul halde iç ve diş piyasalara yüksek fiyatlarla satması katma değerin bu ülkelerde kalmasına ve ODOÜ üreten ülkelerin büyük gelir kayıplarına uğramasına sebebiyet vermektedir (Kurt ve ark., 2011). Bu durum ürünü işleyen ve çeşitlendiren sanayi kolunun önemini açıkça ortaya koymaktadır.

OGM tarafından yaptırılan ODOÜ bitkisel üretimi 2000 yılında 22.000 ton iken, 2013 yılında 246.000 tona çıkmış, aynı dönemde ihracat ise 30,6 milyon \$'dan, 435 milyon \$’a yükselmiştir (Balc1, 2014). 2017 yılında ise OGM'nin ODOÜ üretimi 586.540 ton olarak gerçekleşmiş ve 7.723.623 TL gelir elde edilmiştir (Anonim, 2018). Türkiye'nin ODOÜ olarak iç ve dış ticareti yapılan bitki sayısının 347 olduğu ve bunun yaklaşık \%30'unun ihraç edildiği bildirilmektedir (Kılıç ve Üner, 2009; Yurdaer ve Demirci, 2009).

1990-2009 yılları arasında Türkiye'nin orman ürünleri ihracat ve ithalat verileri baz alınarak yapılan bir çalışmada; ODOÜ ihracat gelirinin yuvarlak odun ihracat gelirine göre çok daha fazla olduğu, ithalatta ise tam tersi bir durumun bulunduğu belirlenmiştir (Kurt, 2011). Türkiye ormanc1lığında, endüstriyel amaçlı ODOÜ üretimi iç ve dış piyasa taleplerine bağlıdır. Talepler incelendiğinde dış piyasa taleplerinin yurt içine göre daha fazla olduğu görülmektedir. Dolayısıyla ihracat şansı yüksek durumdadır (Geray, 1998). X. Beş Yıllık Kalkınma Planı (2014-2018) Sürdürülebilir Orman Yönetimi Özel İhtisas Komisyon (ÖİK) Raporunda, "ODOÜ ve hizmetlerine ilişkin potansiyelin gereğince değerlendirilememesi” ve "orman köylerindeki yoksulluğun sektörde önemli zayıflıklar ve tehditler olarak mevcudiyetini sürdürmesi" zayıfliklar arasında belirtilmektedir (Anonim, 2014b).

Ülkemizde ODOÜ'ne gerçek anlamda ekonomik değer kazandırılabilmek, ormancılık sektörüne ve ülke ekonomisine ciddi boyutta katkı sunabilmek için öncelikle sanayi kolunun mevcut durum ve yapısını tanımak gerekmektedir. Sanayi koluna yönelik saha çalışmasına dayalı incelemelerin ülkemiz genelinde ve Ege bölgesinde çok sınırlı kaldığı görülmektedir.

Türkiye genelinde gerek ODOÜ çeşitliliği ve üretimi, gerekse ticari potansiyeli (ihracat-ithalat) açısından önemli olan Ege Bölgesi, aynı zamanda üretim, üretici, ticaret ve sanayi örgütlerinin yaygınlığı açısından da oldukça etkindir. Bu bölgede yapılacak ODOÜ sanayi kuruluşlarına yönelik çalışmalar, sanayi kolunun tanınması, mevcut durumunun ortaya konulması ve kaynak sahibi olan OGM genelinde ormancılık-sanayi ilişkilerinin geliştirilmesine katkı sağlaması açısından önemlidir.

Konuyla ilgili çalışmalar, daha ziyade ODOÜ ve odun kökenli orman ürünleri sanayi koluna yöneliktir ve ODOÜ sanayi konusunda saha verilerine dayalı çalışma eksikliği dikkat çekmektedir. Bu çalışma ile ODOÜ sanayi, alansal verilere dayalı olarak Ege Bölgesindeki 5 il kapsamında incelenmiştir. Bölge ODOÜ üretimi, üretici, ticaret ve sanayi örgütlerinin yaygınlığı açısından oldukça etkindir. Bölgede yapılacak ODOÜ sanayi kuruluşlarına yönelik çalışmalar, sanayi kolunun tanınmas1, mevcut durumunun ortaya konulmas1, beklenti ve sorunlarının belirlenmesi, gelişimine yönelik 
tespitlerin yapılabilmesi ve kaynakların sahibi olan OGM genelinde ormancılık-sanayi ilişkilerinin geliştirilmesine katkı sağlaması açısından önemlidir. Çalışma ile elde edilen bulgular doğrultusunda öneriler geliştirilmiştir.

\section{Materyal ve Yöntem}

\subsection{Materyal}

Bu araştırma, Ege Bölgesi’nde ODOÜ sanayi işletmelerinin yaygın olarak bulunduğu İzmir, Manisa, Aydın, Denizli ve Muğla illerinde yürütülmüştür. Çalışmanın materyali birincil ve ikincil veri kaynaklarıdır. Çalışmanın ana materyali, Manisa, İzmir, Denizli, Muğla, Aydın illerinde odun dışı ürünler alanında faaliyet gösteren işletme sahipleri/temsilcileri ile yüz yüze yapılan görüşmelerden elde edilen veriler ile oluşturulmuştur (OGM, 2019).

\subsection{Yöntem}

Çalışma ankete dayalı olup araştırma alanındaki odun dişı orman ürünleri işleyen işletmelerin genel özelliklerini belirlemeyi ve mevcut durumlarını genel olarak ortaya koymayı amaçlamaktadır. Bu amacı gerçekleştirmek üzere çalışma alanında faaliyet gösteren işletmelere yönelik soru formları hazırlanmıştır. Çalışma alanındaki kurumlarla resmi yazışmalar yapılmış işletmeler hem yazışmalar yoluyla, hem de saha araştırmalarıyla tespit edilmiştir.

Alanda faaliyet gösteren işletme sayısının sınırlı olması nedeniyle tespit edilen ve görüşmeyi kabul eden tüm işletmeler çalışmaya dahil edilmiştir. Bu kapsamda 105 işletme sahibi/temsilcisi ile görüşülmüştür. İşletmelere, yıllık net satış hasılatı sorulmuş, ancak cevap vermek istememeleri üzerine soru formundan bu soru çıkarılmıştır.

\section{Bulgular}

Çalışma kapsamında toplam 105 görüşme yapılmış olup bunun 46's1 işletme sahibi ve 59'u işletme temsilcisidir. Tablo 1'de 86's1 erkek ve 19'u kadınlardan oluşan işletme sahibi ve işletme temsilcilerinin yaş ve öğrenim durumlarının sayı ve oranları görülmektedir.

Tablo 1. Yaş, öğrenim ve cinsiyet durumu

Table 1. Descriptive statics of age, education and gender

\begin{tabular}{|c|c|c|c|c|c|c|c|}
\hline \multirow{2}{*}{\multicolumn{2}{|c|}{ Say1 }} & \multicolumn{2}{|c|}{ İşletme sahibi } & \multicolumn{2}{|c|}{$\begin{array}{c}\text { İşletme sahibini } \\
\text { temsil yetkisi olan } \\
\text { yönetici }\end{array}$} & \multicolumn{2}{|c|}{ Toplam } \\
\hline & & $\%$ & Say1 & $\%$ & Say1 & $\%$ & \\
\hline & Erkek & 42 & 40,0 & 44 & 41,9 & 86 & 81,9 \\
\hline & Kadın & 4 & 3,8 & 15 & 14,3 & 19 & 18,1 \\
\hline & Toplam & 46 & 43,8 & 59 & 56,2 & 105 & 100,0 \\
\hline \multirow{5}{*}{$\underset{\sim}{\mathbb{*}}$} & $25-34$ & 13 & 12,4 & 29 & 27,6 & 13 & 12,4 \\
\hline & $35-44$ & 11 & 10,5 & 23 & 21,9 & 11 & 10,5 \\
\hline & $45-60$ & 50 & 47,6 & 41 & 39,1 & 50 & 47,6 \\
\hline & $61 \leq$ & 31 & 29,5 & 12 & 11,4 & 31 & 29,5 \\
\hline & Toplam & 105 & 100 & 105 & 100 & 105 & 100 \\
\hline \multirow{7}{*}{ : } & İlkokul & 17 & 16,2 & 15 & 14,3 & 17 & 16,2 \\
\hline & Ortaokul & 10 & 9,5 & 7 & 6,7 & 10 & 9,5 \\
\hline & Lise & 34 & 32,4 & 22 & 21 & 34 & 32,4 \\
\hline & Ön lisans & - & - & 1 & 1 & - & - \\
\hline & Lisans & 44 & 41,9 & 57 & 54,3 & 44 & 41,9 \\
\hline & Lisans üstü & - & - & 3 & 2,9 & - & - \\
\hline & Toplam & 105 & 100 & 105 & 100 & 105 & 100 \\
\hline
\end{tabular}

\section{1. İşletmelerin genel özellikleri}

İşletme çalışan sayısı "Küçük ve Orta Büyüklükteki İşletmelerin Tanımı, Nitelikleri ve Sınıflandırılması Hakkında Yönetmelik”te kullanılan sinıflandırma (Anonim, 2005) esas alınarak değerlendirilmiş; 10'dan az çalışanı olan işletmelerin (mikro işletmeler) oranının \%41,9 olduğu; 10-49 arasında çalışana sahip işletmelerin (küçük işletmeler) \%47,6 oranında olduğu; 250 ve üzeri çalışan sayısı grubundaki işletme oranının ise yalnızca \%1 olduğu belirlenmiştir (Tablo 2).

Çalışanlar, işletmede çalıştıkları bölüme ve cinsiyete göre, ayrıca çalışma sürelerine (daimi/geçici) göre sınıflandırılarak değerlendirilmiştir. Buna göre işletmeler genelinde ortalama çalışan sayısının 33,8 olduğu, bu rakamın 24,9'unu daimi, 
8,9'unu ise geçici çalışanların oluşturduğu görülmüştür. 105 işletmeden 91 adedinde kadın çalışan bulunmaktadır.

Tablo 2. Çalışan sayısı Table 2. Number of employees

\begin{tabular}{lcc}
\hline Çalışan sayıs1 & Say1 & Oran $(\%)$ \\
\hline$<10$ & 44 & 41,9 \\
$10-49$ & 50 & 47,6 \\
$50-249$ & 10 & 9,5 \\
$>=250$ & 1 & 1,0 \\
Toplam & 105 & 100,0 \\
\hline
\end{tabular}

Daimi yönetici kadrosunda kadın bulunan işletme sayısı 44'tür. Geçici personel çalıştıran işletme sayısı 27; bu işletmelerde kadın işçiye de yer veren işletme sayısı 24'tür. Kadın çalışanların genel ortalamasının daha yüksek olduğu; çalışılan bölümlere göre incelendiğinde ise üretim ve pazarlama bölümlerinde kadın çalışan ortalamasının daha yüksek, yönetici kadın çalışan ortalamasının daha düşük olduğu görülmektedir (Tablo 3).

İşletmelerin $\% 53,3$ ile büyük bölümünün limited şirket olduğu; \%28,6'sının ise şahıs işletmesi olduğu görülmektedir. İşletmelerin \%54,3'ünün ortağ1 bulunmaktadır. Bu ortaklık yapısının önemli bir bölümünü ise aile dışı ortaklık $(\% 68,4)$ oluşturmaktadir (Tablo 4).

Tablo 3. Cinsiyet ve çalışılan alan

Table 3. Gender and department

\begin{tabular}{lccccccc}
\hline \multirow{2}{*}{ Çalışan niteliği Kadın } & \multicolumn{3}{c}{ Erkek } & \multicolumn{2}{c}{ Toplam } \\
\cline { 2 - 7 } & Ortalama & Minimum & Maksimum & Ortalama & Minimum & Maksimum & Ortalama \\
\hline Yönetici & 1,7 & 1 & 10 & 2,0 & 1 & 8 & 3,7 \\
Pazarlamacı & 2,3 & 1 & 15 & 1,9 & 1 & 10 & 4,2 \\
Teknik eleman & 1,6 & 1 & 3 & 2,0 & 1 & 10 & 3,5 \\
Büro çalışanı & 1,7 & 1 & 12 & 2,0 & 1 & 10 & 3,6 \\
Üretim işçisi & 13,1 & 1 & 210 & 8,6 & 1 & 166 & 21,7 \\
Güvenlik & - & - & - & 1,4 & 1 & 3 & 1,4 \\
Daimi çalışan & 12,7 & 1 & 250 & 12,3 & 1 & 204 & 24,9 \\
Geçici çalışan & 5,2 & 1 & 10 & 3,7 & 1 & 10 & 8,9 \\
Toplam çalışan & 17,8 & & & 16,0 & & & 33,8 \\
\hline
\end{tabular}

Tablo 4. İșletmelerin hukuki yapıları Table 4. Legal structures of the enterprises

\begin{tabular}{lcc}
\hline İsletmelerin hukuki yapısı & Sayı & Oran (\%) \\
\hline Şahıs işletmesi & 30 & 28,6 \\
Anonim & 15 & 14,3 \\
Limited & 56 & 53,3 \\
Kooperatif & 4 & 3,8 \\
Toplam & 105 & 100,0 \\
\hline
\end{tabular}

İşletmelerin \%98,1’i yatırımlar dahil olmak üzere sermaye olarak öz kaynaklarını kullandığını belirtirken banka kredisi kullandığını ifade edenler \%21,0 olmuş; devlet desteklerinden de yararlandığını belirten işletmelerin oranı ise yalnızca \%1,9 olmuştur (Tablo 5).

\section{2. İșletmelerin faaliyetleri}

İşletmelerin faaliyet alanları gruplandırılmış, diğer iş kollarında da faaliyet gösteren işletme olup olmadığı araştırılmıştır. Farklı bir iş kolunda faaliyet gösteren işletme ile karşılaşılmamıştır. Görüşülen işletmelerin \%32,4’ünün sadece ODOÜ paketleme ve ticareti yaptığı görülmüştür (Tablo 6).

Tablo 5. İşletmelerin sermaye kaynakları ve ortaklık durumu

Table 5. Capital resources and partnership status of the enterprises

\begin{tabular}{lrcccc}
\hline Sermaye kaynakları* & Say1 & Oran (\%) & Ortaklık durumu & Say1 & Oran (\%) \\
\hline Öz kaynaklar & 103 & 98,1 & Var & 57 & 54,3 \\
Banka kredileri & 22 & 21,0 & Yok & 48 & 45,7 \\
Devlet desteği & 2 & 1,9 & Aile dişından & 39 & 68,4 \\
& & & Aile içi ortaklık & 18 & 31,6 \\
*Birden fazla seçenek işaretlenmiştir. & & &
\end{tabular}


Tablo 6. İşletmelerin faaliyet alanları

Table 6. Business area of the enterprises

\begin{tabular}{lrc}
\hline Faaliyet alanı & Sayı & Oran (\%) \\
\hline Odun dışı orman ürünü paketleme ve ticaret & 34 & 32,4 \\
Odun dışı orman ürünü paketleme ve ticaret ile birlikte diğer iş kolları & - & - \\
Odun dışı orman ürünü üretim, paketleme ve ticareti & 71 & 67,6 \\
Odun dışı orman ürünü üretim, paketleme ve ticareti ile birlikte diğer iş kolları & - & - \\
\hline
\end{tabular}

Ürün listesinin oluşturulmasında, Orman Genel toplamı itibarıyla en çok işlenen ürünler kekik (61), Müdürlüğünün "Odun dışı Ürünler Tarife Bedeli defne (55), adaçayı (46) ve biberiye (41) olarak beCetveli” esas alınmıştır (Anonim, 2015). İşletmeler lirlenmiştir (Tablo 7).

Tablo 7. İşletmeler itibarıyla işlenen ürün dağılımı

Table 7. Distribution of processed products by the businesses

\begin{tabular}{|c|c|c|c|c|c|}
\hline Ürün Ad1 & $\begin{array}{c}\text { İşleyen } \\
\text { Firma } \\
\text { Sayıs1 }\end{array}$ & Ürün Adı & $\begin{array}{c}\text { İşleyen } \\
\text { Firma } \\
\text { Sayıs1 } \\
\end{array}$ & Ürün Ad1 & $\begin{array}{c}\text { İşleyen } \\
\text { Firma } \\
\text { Say1s1 } \\
\end{array}$ \\
\hline Kekik (Lamiaceae) & 61 & Hatmi (Malvaceae) & 14 & Reçine & 3 \\
\hline Defne (Laurus nobilis) & 55 & Safran (Crocus sativus) & 14 & Sarısolmaz (Helichrysum sp.) & 3 \\
\hline Adaçayı (Salvia sp.) & 46 & Bal & 13 & $\begin{array}{l}\text { Güzelavratotu (Atropa bella- } \\
\text { donna) }\end{array}$ & 2 \\
\hline $\begin{array}{l}\text { Biberiye (Rosmarinus offici- } \\
\text { nalis) }\end{array}$ & 41 & Mersin (Myrtus communis) & 13 & Ayı üzümü (Vaccinium sp.) & 1 \\
\hline Kimyon (Cuminum cyminum) & 35 & Şerbetçi otu (Humulus lupulus) & 13 & Cehri (Rhamnus sp.) & 1 \\
\hline Çamfıstığ 1 (Pinus pinea) & 29 & Aslanpençesi (Alchemilla sp.) & 11 & Eğrelti otu (Pteridium sp.) & 1 \\
\hline Rezene (Foeniculum vulgare) & 29 & Oğul otu (Melissa officinalis) & 10 & Geven (Astragalus sp.) & 1 \\
\hline Ihlamur (Tilia sp.) & 28 & Böğürtlen (Rubus sp.) & 9 & Kocayemiş (Arbutus unedo) & 1 \\
\hline Kuşburnu (Rosa canina) & 23 & Sakız (Pistacia lentiscus) & 9 & Mantar & 1 \\
\hline Ceviz (Juglans regia) & 21 & Kına otu (Balsaminaceae) & 8 & S1klamen (Cyclamen sp.) & 1 \\
\hline Sumak (Rhus coriaria) & 21 & Sığırkuyruğu (Verbascum sp.) & 7 & Üvez (Sorbus sp.) & 1 \\
\hline Meyan kökü (Glyyrrhiza sp.) & 20 & Sığla (Liquidambar orientalis) & 7 & $\begin{array}{l}\text { Yılan bıçağı (Dracunculus vul- } \\
\text { garis) }\end{array}$ & 1 \\
\hline Isırgan otu (Urtica sp.) & 19 & Çitlembik (Celtis sp.) & 6 & Zakkum (Nerium oleander) & 1 \\
\hline Kantaron (Hypericum sp.) & 19 & Polen & 6 & & \\
\hline Papatya (Asteraceae) & 19 & Salep (Orchidaceae) & 6 & Censiyan (Gentiana lutea) & - \\
\hline $\begin{array}{l}\text { Lavanta (Lavandula angus- } \\
\text { tifolia) }\end{array}$ & 18 & Yoğurt çiçeği (Galium sp.) & 6 & Delice (Olea europaea) & - \\
\hline $\begin{array}{l}\text { Keçiboynuzu (Ceratonia } \\
\text { siliqua) }\end{array}$ & 17 & $\begin{array}{l}\text { Adamotu (Mandragora offi- } \\
\text { cinalis) }\end{array}$ & 5 & Devetabanı (Monstera deliciosa) & - \\
\hline $\begin{array}{l}\text { Mercanköşk (Origanum vul- } \\
\text { gare) }\end{array}$ & 17 & Çakşırı otu (Ferula sp.) & 5 & Gölsoğanı (Leucojum aestivum) & - \\
\hline Okaliptüs (Eucalyptus sp.) & 17 & Kapari (Capparis spinosa) & 5 & Kardelen (Galanthus sp.) & - \\
\hline Funda (Erica sp.) & 16 & Kestane (Castanea sativa) & 5 & Menengiç (Pistacia terebinthus) & - \\
\hline Hayit (Vitex agnus-castus) & 16 & Kendir otu (Cannabis sativa) & 4 & Porsuk (Taxus baccata) & - \\
\hline Mahlep (Prunus mahaleb) & 16 & Laden (Cistus sp.) & 4 & $\begin{array}{l}\text { Sarı kokulu karçiçeği (Eranthis } \\
\text { hyemalis) }\end{array}$ & - \\
\hline Ardıç (Juniperus sp.) & 15 & Mazı & 4 & & \\
\hline Hardal (Sinapis arvensis) & 15 & Mürver (Sambucus sp.) & 3 & Yer çileği (Fragaria vesca) & - \\
\hline Alıç (Crataegus sp.) & 14 & Palamut & 3 & & \\
\hline
\end{tabular}

İşletmelerin faaliyetini yaptıkları ürünlerin işlenme biçimine göre dağılımının incelenmesinde, ayıklama ve temizleme işlemlerinin ardından paketleme, yağ eldesi, su eldesi, toz haline getirme ve diğer ürünlerle karıştırma şeklinde bir sınıflandırma yapılmıştır. Ürünlerin büyük bir bölümünün ayıklama ve temizleme işlemlerinden sonra paket- lendiği ve hammadde şeklinde satışa sunulduğu görülmektedir (Tablo 8).

\section{3. İşlenen ürünlerin pazarlanma şekli}

İşletmelerin ürünleri hangi aşamalarda pazarladıkları araştırılmıştır. Ürünlerini hammadde olarak pazarlayan işletmelerin oran1 $\% 92,4$; su, 
Tablo 8. İşlenme biçimine göre ürünler

Table 8 . Products by processing method

\begin{tabular}{|c|c|c|c|c|c|c|}
\hline Ürün & Yăg & $\mathrm{Su}$ & Toz & Paketleme & Karıştırma & Mamul ürün \\
\hline Adaçayı (Salvia sp.) & 7 & 4 & 14 & 40 & & Çay, gıda takviyesi, granül, sabun \\
\hline Alıç (Crataegus sp.) & 1 & - & 1 & 13 & & \\
\hline Ardıç (Juniperus sp.) & 3 & 1 & 1 & 14 & & Krem \\
\hline Aslanpençesi (Alchemilla sp.) & - & - & - & 9 & & Çay, gıda takviyesi \\
\hline Bal & & & & 12 & 1 & Balmumu, krem \\
\hline Biberiye (Rosmarinus officinalis) & 11 & 6 & 7 & 35 & 1 & Granül, çay, gida takviyesi \\
\hline Böğürtlen (Rubus sp.) & - & 1 & 3 & 8 & & Reçel \\
\hline Çakşır otu (Ferula sp.) & - & 1 & 1 & 5 & & \\
\hline Çamfıstığı (Pinus pinea) & & & & 28 & & Ayıklama \\
\hline Ceviz (Juglans regia) & 8 & & & 18 & & Macun, reçel \\
\hline Çitlenbik (Celtis sp.) & 1 & & & 5 & & \\
\hline Defne (Laurus nobilis) & 14 & 7 & 9 & 50 & & Granül, sabun \\
\hline Funda (Erica sp.) & - & 3 & 1 & 12 & & Çay \\
\hline Geven (Astragalus sp.) & & & & & & G1da takviyesi \\
\hline Güzelavrat otu (Atropa belladonna) & & & & 2 & & \\
\hline Hardal (Sinapis arvensis) & 1 & & & 14 & 1 & Macun \\
\hline Hatmi (Malvaceae) & 1 & & 2 & 13 & & Macun, gida takviyesi \\
\hline Hayit (Vitex agnus-castus) & & 2 & 3 & 12 & & Macun, g1da takviyesi \\
\hline Ihlamur (Tilia sp.) & & 2 & 8 & 24 & & Granül, çay, gida takviyesi \\
\hline Isırgan otu (Urtica sp.) & 1 & 4 & 5 & 16 & & Macun, çay, gida takviyesi \\
\hline Kantaron (Hypericum sp.) & 7 & & 2 & 14 & 1 & Macun \\
\hline Kapari (Capparis spinosa) & & & & 2 & & Turşu, konserve \\
\hline Keçiboynuzu (Ceratonia siliqua) & 1 & & 1 & 15 & & Pekmez \\
\hline Kekik (Lamiaceae) & 13 & 7 & 12 & 2 & & \\
\hline Kendir (Cannabis sativa) & 1 & & & 3 & & \\
\hline Kestane (Castanea sativa) & & & & 5 & & \\
\hline Kimyon (Cuminum cyminum) & 3 & & 5 & 35 & 2 & Macun \\
\hline Kına otu (Balsaminaceae) & & & & 8 & & \\
\hline Kocayemiş (Arbutus unedo) & & & & 1 & & \\
\hline Kuşburnu (Rosa canina) & 2 & & 3 & 18 & 1 & Çay, gıda takviyesi \\
\hline Laden (Cistus sp.) & & & 1 & 4 & & \\
\hline Lavanta (Lavandula angustifolia) & 5 & & 1 & 14 & 1 & \\
\hline Mahlep (Prunus mahaleb) & & & 1 & 15 & & \\
\hline Mantar & & & & 1 & & \\
\hline Mazi & & & & 4 & & \\
\hline Mercanköşk (Origanum vulgare) & & & 2 & 15 & & \\
\hline Mersin (Myrtus communis) & 2 & 2 & 2 & 10 & & Çay \\
\hline Meyan kökü (Glyyrrhiza sp.) & & & 1 & 18 & & G1da takviyesi \\
\hline Mürver (Sambucus sp.) & & & & 2 & & Gıda takviyesi \\
\hline Oğulotu (Melissa officinalis) & & & 1 & 8 & & Macun, çay \\
\hline Okaliptus (Eucalyptus sp.) & 2 & 2 & 1 & 15 & & \\
\hline Palamut & & & & 3 & & \\
\hline Papatya (Asteraceae) & 1 & 3 & 7 & 16 & & Gida takviyesi \\
\hline Polen & & & & 6 & & \\
\hline Reçine & & & & 3 & & \\
\hline Rezene (Foeniculum vulgare) & 2 & 1 & 8 & 25 & 1 & \\
\hline Safran (Crocus sativus) & & & 1 & 13 & 1 & Macun \\
\hline
\end{tabular}


yağ ve toz haline getirerek ya da diğer ürünlerle karıştırarak yarı mamul halde pazarlayanların oranı \%22,9; sabun, parfüm, g1da takviyesi vb. mamul halde pazarlayanların oranı ise yalnızca \%12,4'tür. Tüm işletmelerin \%22,9'unu oluşturan yarı mamul üretim yapan 24 işletme içinde, yăg ve toz eldesi şeklinde üretim oranı sırasıyla $\% 70,8$ ve $\% 62,5$ olarak en fazla gerçekleştirilen üretim biçimleri olmuştur (Tablo 9).

Tablo 9. Ürünlerin pazarlanma şekli

Table 9. Marketing of the products

\begin{tabular}{lcccccc}
\hline Ürün pazarlama biçimi & Sayı & \% & Yarı mamul ürün biçimi & Say1 & $\begin{array}{l}\text { Oran } \\
(\%)\end{array}$ \\
\hline Hammadde olarak (seçme, ayıklama, ambalajlama vb.) & 97 & 92,4 & Suyunu elde etme & 7 & 92,4 \\
Yarı mamul olarak & 24 & 22,9 & Yağını elde etme & 17 & 22,9 \\
Mamul olarak & 13 & 12,4 & Tozunu elde etme & 15 & 62,5 \\
& & & Diğer ürünlerle karıştırma & 1 & 4,2 \\
\hline
\end{tabular}

Mamul üretim biçimleri ise sabun, kolonya, parfüm, krem, valeks, gıda takviyesi, macun, turşu, konserve, çay, reçel ve pekmezdir. Toplam işletme- lerin $\% 12,4$ 'ü oluşturan mamul üretim yapan işletmeler en çok gida $(\% 61,4)$ üretimiyle uğraşmaktadirlar (Tablo 10).

Tablo 10. Mamul üretim

Table 10. Finished products

\begin{tabular}{lcc}
\hline Mamul ürün biçimi & Sayı & Oran (\%) \\
\hline Sabun & 3 & 23,1 \\
Kozmetik (parfüm, krem, kolonya) & 4 & 30,7 \\
Gıda (macun, turşu, konserve, çay, reçel, pekmez) & 8 & 61,5 \\
Gıda takviyesi & 2 & 15,4 \\
İlaç & - & - \\
Valeks & 1 & 7,7 \\
Boyar madde & - & - \\
\hline
\end{tabular}

Üretimin önemli bir kısmının $(\% 71,4)$ yurt içinde konuyla ilgili diğer şirketlere yapıldı̆̆ 1 görülmektedir. Doğrudan tüketiciye satış yapan işletmelerin oran1 \%34,3; aracılara satanların

oranı \%30,5 olmuştur. Ürünlerini yurt dışına da pazarladığını ifade eden işletmelerin oranı ise \%39,1'dir (Tablo 11).

Tablo 11. Ürünlerin pazarlanma yerleri Table 11. Marketing places of the products

\begin{tabular}{lcc}
\hline Ürünlerin pazarlanma yeri & Sayı & Oran (\%) \\
\hline Şirketlere & 75 & 71,4 \\
Yurt dişına & 41 & 39,1 \\
Tüketicilere & 36 & 34,3 \\
Aracılara & 32 & 30,5 \\
Kooperatiflere & 4 & 3,8 \\
\hline
\end{tabular}

En çok tercih edilen pazarlama kanalının, çalışanları yoluyla yapılan doğrudan pazarlama olduğu $(\% 96,2)$ görülmüştür (Tablo 12).

Pazarlamada karşılaşılan sorunlar incelenmiş ve pazarlamada sorunu olmadığını belirtenlerin ora- nı \%19'da kalırken, pazarlama aşamasında en çok karşılaşılan sorunların bütçe ve tahsilat sıkıntıları olduğu görülmüştür (Tablo 13).

İşletmelerin büyük bir bölümünün ürün teminini özel kuruluşlardan ve/veya kişilerden yaptığ 
Tablo 12. Pazarlama kanallar1

Table 12. Marketing channels

\begin{tabular}{lccccc}
\hline Pazarlama kanalı & Sayı & $\begin{array}{c}\text { Oran } \\
(\%)\end{array}$ & $\begin{array}{c}\text { Kullanım oranının } \\
\text { ortalaması (\%) }\end{array}$ & $\begin{array}{c}\text { Minimum } \\
(\%)\end{array}$ & $\begin{array}{c}\text { Maksimum } \\
(\%)\end{array}$ \\
\hline Çalışanlarla doğrudan & 101 & 96,2 & 80,9 & 10,0 & 100,0 \\
İnternetle doğrudan & 22 & 21,0 & 28,9 & 10,0 & 100,0 \\
Aracılarla (acente, komisyoncu) & 21 & 20,0 & 35,0 & 5,0 & 100,0 \\
Perakendecilerle & 12 & 11,4 & 35,0 & 10,0 & 85,0 \\
Toptancılarla & 21 & 20,0 & 25,5 & 10,0 & 100,0 \\
\hline
\end{tabular}

Tablo 13. Pazarlamada karşıllaşılan sorunlar

Table 13. Problems in marketing

\begin{tabular}{lcc}
\hline Pazarlamada karşılaşlan sorunlar & Sayı & Oran (\%) \\
\hline Pazarlama konusuna yeterli bütçe ayıramamaları & 25 & 23,8 \\
Satılan ürün bedellerinin tahsil edilmesinde zorluklar & 15 & 14,3 \\
Devlet teşviği olmaması & 12 & 11,4 \\
Nakliyatla ilgili sorunlar & 11 & 10,4 \\
Tanıtım yetersizliği & 8 & 7,6 \\
Fiyat sorunu & 5 & 4,7 \\
Hedef kitleye ulaşamama & 2 & 1,9 \\
Haksız rekabet & 2 & 1,9 \\
Organizasyonların (kooperatif, sivil toplum örgütleri vb) etkin olmaması & 1 & 1,0 \\
Güven sorunu & 1 & 1,0 \\
Kaliteli hammadde & 2 & 2,0 \\
Gerekli izinlerin alınamaması & 1 & 1,0 \\
Yok & 20 & 19,0 \\
Toplam & 105 & 100,0 \\
\hline
\end{tabular}

doğrudan Orman Genel Müdürlüğünden temin et- İșletmelerin hammadde temin kaynaklarının

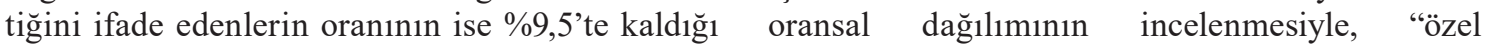
görülmüştür.

kişilerden elde edilme" payının ortalama \%79,3;

Tablo 14. Hammadde temin yeri

Table 14. Raw material supply place

\begin{tabular}{lcc}
\hline Hammadde temin yeri & Sayı & Oran (\%) \\
\hline Doğrudan Orman Genel Müdürlüğünden & 10 & 9,5 \\
Özel kişilerden & 88 & 83,8 \\
Özel kuruluşlardan & 36 & 34,3 \\
Yurt dişından & 8 & 7,6 \\
Doğadan & 1 & 0,9 \\
Kendi arazisinden & 1 & 0,9 \\
\hline
\end{tabular}

“özel kuruluşlardan elde edilme” payının ortalama \%69,6 olduğu; Orman İdaresini hammadde temin kaynakları arasında gösteren \% $\%, 5$ oranındaki işletmenin ise toplam hammadde temin kaynakları arasındaki payının ortalama \%67,0'1nı bu yolla elde ettiği görülmüştür (Tablo 15).

Hammadde temin kaynakları arasında yurt dışını belirten $\% 7,6$ oranındaki işletmeye, ithal ürün tercih etmelerinin sebebi sorulmuş ve yerli hammad- 
Tablo 15. Hammadde temin kaynaklarının toplam içindeki oranı

Table 15. Proportion of raw material supply resources in total

\begin{tabular}{lcccc}
\hline $\begin{array}{l}\text { Tanımlayıc1 } \\
\text { istatistik }\end{array}$ & $\begin{array}{c}\text { Doğrudan } \\
\text { orman } \\
\text { idaresinden }\end{array}$ & $\begin{array}{c}\text { Özel } \\
\text { kişilerden }\end{array}$ & $\begin{array}{c}\text { Özel } \\
\text { kuruluşlardan }\end{array}$ & $\begin{array}{c}\text { Yurt } \\
\text { dişından }\end{array}$ \\
\hline Say1 & 10 & 88 & 36 & 8 \\
Ortalama (\%) & 67,0 & 79,3 & 69,6 & 29,4 \\
Ortanca & 70,0 & 100,0 & 72,5 & 25,0 \\
Minimum & 25 & 10 & 15 & 5 \\
Maksimum & 100 & 100 & 100 & 90 \\
1. Kartil & 30,0 & 60,0 & 46,3 & 10,0 \\
3. Kartil & 100,0 & 100,0 & 100,0 & 37,5 \\
\hline
\end{tabular}

denin miktar ve kalite bakımından yetersizliği en İșletmelerin araştırma-geliștirme (Ar-Ge) faaliçok ifade edilen sebepler olmuştur (Tablo 16). yetlerine yönelik birimleri olup olmadığı ve bu birimlerin amaçları ile çalışan sayısı incelenmiş

Tablo 16. İthal ürün tercih nedenleri

Table 16. Imported product preference reasons

\begin{tabular}{lcc}
\hline İthal hammadde tercih nedenleri & Sayı & Oran (\%) \\
\hline Yerli hammadde miktarı yetersiz & 4 & 50,0 \\
Yerli hammadde kalite bakımından yetersiz/ İthal ürünün kalitesi daha yüksek & 3 & 37,5 \\
İthal hammadde daha ucuz & 2 & 25,0 \\
Tüketici ithal ürünü daha fazla talep ediyor & 1 & 12,5 \\
Türkiye'de piyasası bittiği zaman (diğer) & 1 & 12,5 \\
Yerli ürün istenilen dönemde bulunmadığından & 1 & 12,5 \\
Çeşit bulundurmak açısından & 1 & 12,5 \\
\hline
\end{tabular}

* Birden fazla seçenek işaretlenmiştir.

ve \%16,2'sinin Ar-Ge bölümüne sahip olduğu görülmüştür.

Ar-Ge bölümü olan işletmelerin bu alandaki faaliyetleri ve hedefleri "üretime yeni ürün katma", "yeni ürün geliștirme", "üretim teknolojisini geliştirme" ve "diğer" seçenekleri ile araştırılmıştır. Ar-Ge ile ilgili hedeflerin yeni ürün geliştirme ile üretime yeni ürün katma olduğu görülmüştür (Tablo 17). İşletmelerin \%64.7'inin Ar-Ge birimlerinde ortalama 2 kişi çalıştırıldığı görülmüştür.

\section{Tartış̧ma ve Sonuç}

Çalışma ile Ege Bölgesinde Manisa, İzmir, Aydın, Muğla, Denizli ve İzmir illerinde odun dışı orman

Tablo 17. İşletmelerin Araștırma-Geliștirme durumları

Table 17. Research\&Development status of the enterprises

\begin{tabular}{llcc}
\hline & & Sayı & Oran (\%) \\
\hline \multirow{4}{*}{ AR-GE birimi } & Var & 17 & 16,2 \\
& Yok & 88 & 83,8 \\
& Toplam & 105 & 100,0 \\
& Yeni ürünleri üretime katmak & 4 & 20 \\
& Yeni ürün geliştirmek & 16 & 80 \\
AR-GE amaçları & Üretim teknolojisi geliştirmek & -- & -- \\
& Diğer & & \\
\hline
\end{tabular}


ürünleri sanayinin mevcut durumu ile ilgili veriler elde edilmiştir. İşletmelerin genel profilinin değerlendirilmesi ile \%89,5'ini mikro ve küçük ölçekli işletmelerin oluşturduğu, büyük ölçüde öz kaynakları ile faaliyet gösteren pazarlama olanakları zayıf ve sermayeleri sınırlı işletmeler oldukları görülmektedir (Gölükçü ve ark., 2012) tarafından Batı Akdeniz yöresindeki tıbbi ve aromatik bitkileri işleyen işletmelerin örnekleme yoluyla incelendiği çalışma bulguları ile de mevcut yapının genelde aile işletmesi, fiziki alt yapısı yetersiz ve ağırlıkla öz kaynak kullanan nitelikte olduğu, üretim aşamasında yeterli ve kaliteli hammaddeye ulaşmada güçlük yaşandığı, örgütlenmelerinin yetersiz olduğu, rekabet ve bilgiye ulaşımda zorlukların bulunduğu belirtilmektedir.

İncelenen işletmelerin genel olarak kurumsallaşma sürecinin başında oldukları belirlenmiştir. İşletmelerin profesyonel yönetilmeleri için uzman kişileri istihdam etmeleri sağlanmalıdır. Ancak işletmelerin mevcut yapıları itibarıyla bu sorunu kendi içlerinde çözmelerinin zor olduğu görülmektedir. Bu nedenle işletmelere destek sağlayacak mekanizmalar oluşturulması önemlidir.

Sektörde yönetim ve bilgi eksikliği çok fazla olup iş geliştirme ve kapasite artırma konusunda önemli bir destek ihtiyacı bulunmaktadır. Bu ihtiyacın karşılanması, bilginin etkili paylaşımı, kapasite oluşturma ve geliştirmede ivmenin artırılması ve yeniliklerin hızla yayılabilmesi için yerel, bölgesel, ulusal ve uluslararası birimleri bağlayan süreç ve yapılar oluşturulmalıdır. $\mathrm{Bu}$ nedenle ODOÜ sanayi konusunda ulusal düzeyde iş geliştirme, kapasite artırma ve mevcut bilgi paylaşımını sağlayacak odun dişı orman ürünleri konusunda çalışanları (üretici/toplayıcı, işletmeci, uygulamacı, araştırmacıları) içine alan bir ağ oluşturulması çok önemlidir. Ayrıca, yöresel ve/veya bölgesel düzeyde daha küçük ağların oluşturulması da teşvik edilmelidir.

Başarılı örnekler -başarıdaki etkili faktörler, örneğin kooperatifleşme, sivil toplum kuruluşları ile işbirliği, ihracata yönelme, mamul ürün üretme, devlet teşviklerinden yararlanma ve Orman Genel Müdürlüğ̈̈nün merkez ve taşra (ODOÜ) birimleri ile iletişimde olma gibi faktörlerin öneminin vurgulanması yoluyla- paylaşılarak gerek mevcut işletmelerin, gerekse yeni girişimcilerin odun dişı orman ürünlerine yönelik ilgisi artırılmalı ve gelişmeleri teşvik edilmelidir.

Özel sektör- kamu kurumları - üniversiteler -sivil toplum kuruluşlarının bir araya geldiği oluşumlarla (toplantılar, çalıştaylar, sempozyumlar, konferanslar, ulusal / bölgesel/ yöresel ağlar) sektördeki fa- aliyetler izlenmeli ve konu ile ilgili araştırma ve envanter çalışmaları ile elde edilen bilgiler değerlendirilerek sektör yönlendirilmelidir. Araştırma ve envanter çalışmalarının bulguları ve oluşturulan veri bankaları mevcut işletmelerin ve yeni girişimcilerin alandaki etkinliklerini artıracak biçimde paylaşılmalıdır. Tanımlanan paydaşların bir araya geldiği bu oluşumlar, ihtiyaçları belirleme, bilgi paylaşımı, gelişimi hızlandırma, izleme ve yenilikleri yayma için mutlaka gerçekleştirilmelidir.

Gelişmenin ivmesini artırmak, ilgili tüm tarafları içine alan bütüncül bir yaklaşımla mümkündür. $\mathrm{Bu}$ kapsamda orman kaynaklarının planlanması aşamasında bu bütünlüğün sağlanması ve orman kaynaklarının odun ve odun dışı tüm bileşenleriyle ele alındığı planlamaların gerçekleştirilmesi yönünde yapılacak araştırmalara öncelik verilmelidir.

\section{Teşekkür}

Bu makale, Orman Genel Müdürlüğü, Ege Ormancılık Araştırma Enstitüsü Müdürlüğü'nce yürütülen 15.7711/2015-2018 nolu "Ege Bölgesi Odun D1ş1 Orman Ürünleri Sanayinin Mevcut Durumu ve Gelişme Potansiyeli" adlı projeden hazırlanmıştır. İlgi ve sabırlarıyla bu çalışmanın ortaya çıkmasında en büyük payın sahibi olan anketimizi cevaplayan bütün işletmelere çok teşekkür ederiz.

\section{Kaynaklar}

Anonim, 2004, Türkiye Ulusal Ormancılık Programı (2004-2023), TC Çevre ve Orman Bakanlığı

Anonim, 2005, Küçük ve orta büyüklükteki işletmelerin tanımı, nitelikleri ve sınıflandırılması hakkında yönetmelik, Resmi Gazete Tarihi: 18.11.2005 Resmi Gazete Sayıs1: 25997.

Anonim, 2013, Onuncu Beş Yıllık Kalkınma Planı (2014-2018), (E.T: 28.06.2018) http://www.kalkinma. gov.tr/ Lists/Kalknma\%20Planlar/Attachments/12/ Onuncu_Kalk\%C4\%B1nma_Plan\%C4\%B1.pdf

Anonim, 2014a, Onuncu Beş Yıllık Kalkınma Planı (2014-2018) Sürdürülebilir Orman Yönetimi OİK Raporu, (E.T: 17.07.2018)

Anonim, 2014b, Onuncu Beş Y1llık Kalkınma Planı(20142018) Sürdürülebilir Orman Yönetimi OİK Raporu, (E.T: 17.07.2018 ) http://www.kalkinma.gov.tr/Lists/zel\%20 htisas\%20Komisyonu\%20Raporlar/Attachments/230/ S \% C 3\% B Crd \% C 3 \% B Cr \% C 3\%BClebilir \% 20 Orman\%20Y\%C3\%B6netimi_\%C3\%B6ik.pdf

Anonim, 2015, Orman Genel Müdürlüğü “Odun diş1 Ürünler Tarife Bedeli Cetveli” http://www.ogm.gov.tr/ ekutuphane, (E.T: 25.06.2015).

Anonim, 2016, Orman Genel Müdürlüğü Stratejik Plan1 (2017-2021) (E T: 27.06.2018)https://www.ogm.gov. 
tr/ekutuphane/StratejikPlan/Orman\%20Genel\%20M\% $\mathrm{C} 3 \% \mathrm{BCd} \% \mathrm{C} 3 \% \mathrm{BCrl} \% \mathrm{C} 3 \% \mathrm{BC} \% \mathrm{C} 4 \% 9 \mathrm{~F} \% \mathrm{C} 3 \% \mathrm{BC} \% 20$ Stratejik\%20Plan\%20(2017-2021).pdf

Geray, U. 1998, Orman Kaynaklarının Yönetimi, Ulusal Çevre Eylem Planı, DPT Yayını, ISBN 975-19-1917-7

Gölükçü, M. Tokgöz, H. Toker, R. Çelikyurt, MA. Tuğrulay, S. 2012, Tibbi ve aromatik bitki işletmelerin yap1sal analizi, Batı Akdeniz Tarımsal Araştırma Enstitüsü (BATEM), ISBN 978-605-4672-08-0

Ickowitz, A. Powell, B. Salim, M. Sunderland, T.C.H. 2014, Dietary quality and tree cover in Africa. Global Environmental Change, Vol. 24: 287-294

OGM, 2019, Orman Genel Müdürlüğü, Ege Bölgesi Odun Dışı Orman Ürünleri Sanayinin Mevcut Durumu ve Gelişme Potansiyeli, Ege Ormancılık Araştırma Enstitüsü Müdürlüğü projesi, ProjeNo: 15.7711/2015-2018-2019.

Kurt, R., Çabuk, Y. Karayılmaz S. 2011, Türkiye ve Dünya Yuvarlak Odun ve Odun Dış1 Orman Ürünlerinin Üretim, Dış Ticaret ve Ekonomik Potansiyel Analizi,
Bartın Orman Fakültesi Dergisi, Cilt: 13, Sayı: 20, 1-9, ISSN: 1302-0943

Kurt, R., 2011, Türkiye Odun Dış1 Orman Ürünlerinin Mevcut Durumu ve Dış Ticaret Analizi, Bartın Üniversitesi Fen Bilimleri Enstitüsü, Yüksek Lisans Tezi

Kılıç, M., Üner, M. 2009, Orman Ekosistemlerini İyileştirme ve Biyolojik Çeşitliliği Artırma Çalışmaları. Orman Genel Müdürlüğü İkinci Odun Dışı Orman Ürünleri Paneli, 31-34s.

Türker, M.F., Pak, M., Öztürk,A., Durusoy, İ., 2006, Türkiye'de odun dışı orman ürünlerinin sürdürülebilir işletmeciliği: Mevcut durum, sorunlar ve çözüm önerileri, Uluslararası Odun Dışı Orman Ürünleri Sempozyumu, Trabzon.

Yurdaer, M., Demirci, M., 2009, Odun Dışı Orman Ürünlerinin Planlamasında Karşılaşılan Sorunlar ve Bu Konuda Yapılabilecekler. Orman Genel Müdürlüğü İkinci Odun Dışı Orman Ürünleri Paneli, 24-30s. 